\title{
DOCTOR APOLINARY TARNAWSKI (1851-1943) - THE PIONEER OF NATURAL MEDICINE AND PHYSIOTHERAPY IN GERIATRICS IN POLAND
}

\author{
DOKTOR APOLINARY TARNAWSKI (1851. - 1943.) \\ - PIONIR PRIRODNE MEDICINE I FIZIOTERAPIJE \\ GERIJATRIJSKIH PACIJENATA U POLJSKOJ
}

\author{
Mariusz Migała", Sławomir Jandzisis"
}

\begin{abstract}
SUMMARY
Doctor Apolinary Tarnawski (185I-1943) was undoubtedly the precursor of modern natural medicine, preventive medicine, and geriatric physiotherapy in Poland. Based on the experience gained from foreign scientific travel, own knowledge and experience, he developed an original method that he successfully used in his own clinic in Kosów. His assumptions proved to be timeless, and despite the passage of many years have not lost their relevance.
\end{abstract}

Keywords: history of medicine, physiotherapy, therapeutic gymnastics, physical medicine

* Department of Biomedical Basics of Physiotherapy, Faculty of Physical Education and Physiotherapy, Opole University of Technology; Historical Section of the Polish Society of Physiotherapy, Opole, Poland. ORCID ID: https://orcid.org/0000-0002-9732-1681.

** College of Medical Sciences of the University of Rzeszów; Historical Section of the Polish Society of Physiotherapy, Rzeszów, Poland. ORCID ID: https://orcid. org/0000-0001-6644-1077.

Correspondence Address: Mariusz Migała, Department of Biomedical Basics of Physiotherapy, Faculty of Physical Education and Physiotherapy, Opole University of Technology, Prószkowska 75, 45-758 Opole, Poland.E-mail:m.migala@po.edu.pl. 


\begin{abstract}
Admission
Although the first attempts of treatment with agents found in nature had appeared in Poland before, it is widely believed that it was Dr Apolinary Tarnawski $(185 \mathrm{I}-\mathrm{I} 943)^{1}$ who set the direction for the development of natural medicine by developing his original method ${ }^{2}$. He was also one of the first Polish doctors who raised the importance of issues regarding forms and methods of prevention against early ageing and rescuing people in old age. He developed both these areas in the clinic he founded in 1893 in Kosów Huculski by Rybnica, in Eastern Galicia ${ }^{3}$.
\end{abstract}

1 A graduate of the Faculty of Medicine of the Jagiellonian University in Kraków (1877). Until 1882, he worked as an auxiliary doctor at the Universal Hospital in Lwów in the departments of: internal medicine, gynaecology, skin and venereal surgery, and surgery. He was a co-founder of the Sokól patriotic society. In the years 1878-1880, he was the secretary of the Lwów section of the Society of Galician Doctors. On behalf of the Society, during his leave, he worked as a spa doctor Żegiestów (1879), Morszyn (1881), Wysoka (1883). Until 1896 he worked as a county doctor in Borszczów, Jaworów, and Kosów. Working in Kosów, he noticed the healing properties of its climate. In 1896, he stayed at Dr H. Lahmann near Dresden, where he used the vegetarian diet. After resigning from the function of a county doctor, he dealt exclusively with the construction of a diet and hydrotherapy plant near Kosów, which he started in 1893. Initially, the medical community was distrustful and envious of his idea of natural medicine. As a symbolic sign of reconciliation, he was awarded in 1927 by the Faculty of Medicine of the Jagiellonian University a renewed diploma of medicine doctor on the 50th anniversary of graduation. Dr Tarnawski left Kosów before the Red Army troops took the town, probably before 19 September 1939. He and his family managed to flee to Romania. From there he and his son sent a memorial to the Polish Government in Angers in 1940 regarding the establishment of a treatment facility for sick Poles in France. Then he stayed in Cyprus and Palestine, where he died and was buried in the catacombs of the Franciscan Fathers on Mount Zion. In the medical literature, he gained the nickname "genius from Kosów". Jankowiak, Józef (1962), Profiles of distinguished promoters of natural medicine methods. Biography of Dr Apolinary Tarnawski, Wiadomości Uzdrowiskowe, XVII (1), 84-86; Tarnawska-Busza, Celina (1987), Doctor Apolinary Tarnawski. The precursor of natural medicine and geriatrics in Poland, Problemy Uzdrowiskowe, 29, (9-10), 147-151; Apolinary Tarnawski (2000), [in:] Pruszyńska, Agnieszka (2000), Medical Memorabilia in the Archives of the Polish Institute and the Museum of General W. Sikorski in London, Modern Medicine, 7 (1), 125-127.

2 During the VIII Congress of the Polish Balneological Society, which took place on On May 18-20, 1972, in Szczawnica, Apolinary Tarnawski was officially recognised as the precursor of Polish natural medicine. Cf. (1973), Polish Balneology, XVIII, 1-3, 14.

3 Galicia is the colloquial name of the Kingdom of Galicia and Lodomeria, created on the territory of the Kingdom of Poland which was in the years 1772-1918 under the rule of the Austrian and Austro-Hungarian Empire. Galicia was a province of the Habsburg monarchy, traditionally multinational and multi-faith. Apart from Poles and Ruthenians, Jews, Armenians, and Germans lived there. Lwów was the capital of Galicia. After World War I, most of these lands were within the borders of the reborn Polish state. The territories of Eastern Galicia after World War II belonged to the Soviet Union, and since 1991 have been part of Ukraine. See: Kieniewicz, Stefan (1996), History of Poland 1795-1918, Warszawa, $26-28$. 
Implementing his ideas, he was also an undisputed promoter of a healthy lifestyle among Polish society. However, before he started using his methods on patients, he tried many of them on himself. By working intensively and leading a stressful lifestyle, while indulging himself (cigarettes, coffee, alcohol), he began to suffer from stomach ailments. Therefore, in I89I, in order to save his health, he went to the hydrotherapy plant in Wörishofen, which was run by Rev. Sebastian Kneipp (1821-1897). The stay in Bavaria allowed Dr Tarnawski to learn about the world-famous hydrotherapy method, the idea of natural therapy and the principles of hygienic lifestyle preferred in Wörishofen. The treatment proved effective, which encouraged him to treat other patients in the country with this method ${ }^{4}$.

\section{NATURAl MEDICINE ACCORDING TO TARNAWSKI}

Even before the outbreak of World War I, Dr Tarnawski argued that: "Natural medicine is aimed at [...] sins against nature and their effects. It does this with the help of the means found in nature, i.e. with the help of the sun, air, movement and the appropriate diet. Recommended sun-air baths, breathing fresh air during the day and at night, breathing gymnastics; instructs you to train your muscles in physical work and with gymnastics, and for the weak, use massaging. It encourages abstinence in food and teaches chewing (according to the Fletcher method) and warns against arousal with drinks, tobacco and the like. It cleanses the blood through vegetarian foods or fasts. Hardening through water therapy and walking barefoot; recommends wearing ventilated clothing, sandals, etc." ${ }^{5}$. In turn, when the patient once thanked him for the treatment, he was to say: "thank the sun, thank the air and the principle of abstinence, which you finally understood". He also noted that natural healing begins when a person falls ill and suffers. On the other hand, hygiene, which is supposed to protect people from suffering and make them effective, should be used every day. And according to Tarnawski, such a state could only be achieved through habit and upbringing?

It seems, however, that although interest in natural medicine increased after 1918, public awareness of medicines and hygiene issues was still low,

4 Jandziś, Sławomir, Pleśniak, Andżelika, Zaborniak, Stanisław, Kiljański, Marek (2015), The original natural healing method of Dr Apolinary Tarnawski used at the Plant in Kosów in 1893-1939, Polish Journal of Physiotherapy, XV, 1, 75.

5 Tarnawski, Apolinary (1913), Natural Medicine, Ruch, VIII (12), 159.

6 Tarnawska-Busza, Celina (1980), Dr Apolinary Tarnawski. Pioneer of natural medicine and geriatrics in Poland, Bulletin. Circle of Lwów, XIX (38), 79.

7 Tarnawski, Apolinary (1911), Hygiene on a normal day, Ruch, VI (17-18), 177-182. 
since in 1925 in the introduction to the Dr Tarnawski Health Care Program the author wrote: "Doctors often demand detailed explanations about the method of treatment, especially those who are not familiar with natural medicine. [... At present, we have none, apart from contingent articles published in literary magazines and few works published by physiology supporters, although a general return to nature and hygiene life can be noticed [...], however, there are still various views in this direction - as true as and wrong". Therefore, one of the ideas of Dr Tarnawski was the creation of universities of universal hygiene in all Polish spas. They were supposed to be centres of hygiene propaganda and training on its principles ${ }^{8}$.

\section{TARNAWSKI ON GERIATRICS}

Even before the outbreak of World War II, Tarnawski's thoughts and experiences gained from working in Kosów on the subject of forms and ways to prevent old age were included in the book Hygiene of old age and ageing. In the introduction, he emphasized that: "The present times are unsuccessful for old age [...] old people seem to be a hindrance and are deprived by the society of participating in active life". Probably [...] society [...] deals with the elderly, it even gives them a tolerable pension [...]. But morally, it is even worse for them, old people, because they feel that they are superfluous and disregarded $[. .]$.$" .$

Doctor Tarnawski opposed this approach, which urged him to take an active attitude towards his own struggles with various sufferings, so as not to be sorry, not to break down in suffering, not to accept the attitude of suffering, but to develop the will to live, overcome his own suffering, and cooperate with medical care. He considered old age as the quintessence of all life and experience. He claimed that experienced older men should rule the country. That is why the book treated hygiene of old age and healthy ageing as a social imperative. It was a kind of guidebook on what to do and what to avoid in everyday life so that you can experience your old age actively and remain fit and independent of others for as long as possible. As a basic factor in maintaining health in old age, he recommended fresh air, and since older

8 Tarnawski, Apolinary (1925), Program of Dr Tarnawski's Clinic in Kosów, Lwów, 2; Tarnawska-Busza, C. (1987), 152.

9 Tarnawska-Busza, C. (1987), 152. The book in question was supplemented and published in 1980 by his son Wit Tarnawski (1894-1988), writer and literary critic, a doctor and associate by education. Dr Tarnawski in Kosów. Tarnawski, Apolinary (1980), Hygiene of old age and ageing, London. 
people rarely left the house, he recommended sleeping with the window open or tilted, frequent airing of apartments, walking, regular and breathing gymnastics ${ }^{10}$.

According to Tarnawski, the second important factor in maintaining health in old age was movement. He appealed to older people to do sports and gymnastics adapted to their abilities, do physical work, organise trips, and longer walks. He argued that lack of movement could lead to muscle wasting, leaning, respiratory, and circulatory problems. Therefore, he strongly recommended that seniors regularly walk, preferably in a group, that a walk with friends of a similar age was a pleasure, not a chore. For people who were in full strength to exercise daily gymnastics, he developed special guidelines that were to contribute to a more tangible effect of exercise. For old and sick people who could not get out of bed, he recommended performing simple exercises lying or sitting ${ }^{11}$.

Relaxation was also important in maintaining the condition of seniors, which consisted of lying evenly, raising the lower and upper limbs, and then straining the muscles of the body and holding the breath, counting to ten. Then the body was relaxed, deeply breathed, counting to sixty, and this exercise was repeated 2-3 times. The last element was a vegetarian diet, because, according to Dr Tarnawski's, the elderly should limit foods rich in fats and proteins and consume those that are rich in carbohydrates and contain alkaline nutritional salts, as well as a lot of vitamins ${ }^{12}$.

It seems that the original system of preserving the health of the elderly created by A. Tarnawski was timeless and far ahead of the times in which he lived and worked. For this reason, Dr A. Tarnawski is a pioneer of physiotherapy in geriatrics ${ }^{13}$.

Tarnawski, A. (1980), 27-29.

Ibid., p. 49-57.

12 Ibid., p. 31, 35. For more on the subject of the Tarnawski's natural healing method, read: Jandziś, S., Pleśniak, A., Zaborniak, S., Kiljański, M. (2015), 74-80.

13 Celina Tarnawska-Busza (1905-1999), daughter of Dr Tarnawski and a popularizer of his work, a doctor by profession, believed that her father was a pioneer of geriatrics in Poland. Tarnawska-Busza, C. (1980), 79, 81; and (1987), 154. 


\section{The Clinic In Kosów}

As mentioned earlier, the therapeutic plant founded by A. Tarnawski was located near Kosów, in the village of Smodna (400 m a.s.l.), in the southernmost area of the Second Polish Republic. It was created among the park of fruit and ornamental trees, sheltered from the west and north by mountains, and at a distance of one kilometre by forests (deciduous and coniferous). The average annual air temperature was 9 degrees $\mathrm{C}$ (the highest in all Galicia), the average precipitation $-600-700 \mathrm{~mm}$, the cloudiness was also the lowest in all of Galicia. Spring was the earliest, while winter was the latest. Tarnawski compared the specific climate with few rainy and cloudy days combined with extremely clean air to South Tyrol. Initially, the treatment season lasted from May i to the end of October, and in the rg2os from April I5 to mid-November. It consisted of three parts: spring (April is to mid-June), summer (June 16 to the end of August), and autumn (September to mid-November). At the beginning, the plant was closed in the winter, but over the years, it also offered the use of the outdoor sunbaths, as well as skiing, tobogganing, and skating ${ }^{14}$.

During the First World War, the plant was plundered and devastated. It took Tarnawski a few years to rebuild and restart it, because it did not happen until 1922. Although, after the extension, the number of places in it was increased (250 people played at the opening), the equipment was modest, without much comfort. It was argued that caring for convenience weakens the "will, while independence and healthy instincts are gained through communion with nature" ${ }^{" 15}$. More important than convenience was the use of new treatment methods at the Plant at the time, including hydrotherapy according to the priest Kneipp, vegetarian cuisine according to Dr Heinrich Lahmann (1860-1905), as well as air-solar baths used by Dr Arnold Rikli (I823I906) in Velde ${ }^{16}$.

The plant had already been mentioned among important holiday resorts in Galicia at that time (IgI2), where Dr Tarnawski, using individual elements of the above-mentioned methods of natural medicine, tried to create a "Polish method, easy and understandable, so that it would be accessible to

14 Dr A. Tarnawski, Physical and Dyethetic Therapy Center in Kosów (after Kołomyja) (1904), [in:] Górski, Xawery ed., (1904), Polish Guide to Spas, published by Przegląd Zdrojowy, Kraków, 28-34; Tarnawski, A. (1925), 10; id. (1920), Prospectus of Dr Tarnawski's hygiene clinic in Kosów, Kraków, 24.

15 Ibid., p. 4.

16 Tuchendler, Antoni (1931), Our native natural medicine in Kosów, Nowiny SpołecznoLekarskie, V (9), 148. 
all". The starting point was the assumption that one of the main causes of many diseases is inadequate lifestyle, especially improper nutrition ${ }^{17}$. From here, he urged to develop prevention and spread knowledge about health and hygiene. However, even before the outbreak of the Great War, in the light of the insufficient involvement of doctors in these matters, A. Tarnawski wrote: "individuals, it would be a patriotic act and the public would absorb the news with gratitude" 18 .

After the reconstruction of the Department, he continued to improve his method, which was to create the basics of hygienic life, with which patients could practically familiarise themselves during the treatment, in order to use it in the future after returning home. In addition, he drew attention to the atmosphere prevailing in the plant, which was supposed to be far from the artificial splendour prevailing in European spas.

The fact of reopening the plant was received with great satisfaction among the Polish bohemians, as the clinic had already attracted a lot of interest. After reopening, people from all over Poland came to the plant, and the attendance was so high that, as one of the patients said, "one could form a parade to Wawel”"19.

The fact that the elites of the Second Polish Republic were eagerly awaiting the re-launch is evidenced by the words written after the opening in 1922: "However, in reborn Poland, perhaps more than before, there was a lack of $<$ Kosów $>$, this one-of-a-kind clinic in view of the ruining nerves and physical consequences of the war, Polish tasks are even broader and more substantial than before" 20 . This place was unique, conducive to both relaxation and improving the mental and physical condition of Poles, given that in the interwar

17 Tarnawski, Witt (1966), My Father, London, 133; Lewicki, Stanisław, Orłowicz, Mieczysław, Praschil, Tadeusz (1912), Guide to Galicyi spas and climatic resorts including: spas, spas, health resorts, summer resorts, climatic resorts, and towns with mineral springs, as well as tourist and winter sports facilities, Lwów, 14; Kowalenko, Halina (1973), Apolinary Tarnawski - a precursor of the prevention of civilization-related harm, Polish Balneology, XVIII (1-3), 15-18.

18 Tarnawski, A. (1913), 157.

19 Tarnawska-Busza, C. (1980), 80. Until the outbreak of World War I, Kosów was the second town after Zakopane to which Poles came not only from Galicia, but from all three partitions. Well-known writers, actors, artists, poets, painters, politicians, and convalescents who were repressed for independence activities came there. Thanks to this, Kosów served as a link to the divided homeland. Patients from abroad also came to the Tarnawski Institute, among others from Rome, Bucharest, and even Finland. Kordys, Roman (1922), Undermining the spa, Słowo Polskie, 211/1922. Ibid. 
period, fashion for relaxation away from home, in attractive regions, with distinctive culture and atmosphere became more and more common.

In the new reality, from the very beginning the treatment with $\mathrm{Dr}$ Tarnawski became something unique and fashionable. It belonged to a certain extravagance, not to mention that the fast carried out at the plant took on a snobbish character. However, most people came there to renew their strength and improve their health. This is demonstrated by the influx of patients, which was about 2-3 thousand per year, despite the fact that the stay in the clinic was not the cheapest, with the reservation that the fee varied depending on the type of room ${ }^{21}$.

The treatment at the Treatment Plant in Kosów was not only aimed at improving health because Dr Tarnawski also tried to educate the patients, accustoming them to comply with hygiene rules not only on the premises of the Plant but also at home when they return to normal everyday life. This was facilitated by talks during which he instilled principles of healthy life for patients so that listeners could later use them at home. Two to three times a week, lectures on hygiene were provided by the company's doctors, and from other fields, such as literature, Polish inventions, or the history of old Poland, by speakers from the group of patients ${ }^{22}$. Thanks to this, the Kosów Clinic gained the name of "Modern Health University" after several years of operation. As early as I909, about the Clinic was written: "[...] the Kosów Clinic cannot be included in a number of ordinary natural medicine facilities. Rather, it is a practical university of personal hygiene, or an adult education institution, where patients transform into advocates of a rational lifestyle based on the basics of personal and social hygiene, and being the best means of changing the terrible conditions present" ${ }^{\prime 2}$.

After the plant was rebuilt, the treatment, as before the war, was still managed by the owner himself, who had one doctor to help, sometimes two doctors. The treatment used only natural (physical) remedies, i.e. gymnastics, massage (muscle), sun and air baths on a separate playground for men

21 For example, in 1931, the daily fee for housing, meals, treatments and treatment was in the spring-autumn season from 13 to 17 PLN, and in the summer season from 16 to 20 PLN per person. Spas and spas in Poland. Illustrated guidebook for 1927 (1926), Warszawa, 104-107; Polish spas. Guide to health resorts affiliated to the Association of Polish Spas (1932), Warszawa, 76; Polish Guide Spas (1934), Kraków, 304-306.

22 Tarnawski, Apolinary (1923), Common universities in spas, Polska Gazeta Lekarska, II (23), 413; Seasonal report from the Institute of Natural Medicine Dr Tarnawski in Kosów (1935), [in:] Diary of the Polish Balneological Society (1935), XIV, 304; Kowalenko, H. (1973), 16.

23 Draz, Stefan (1909), Modern university of health, Ruch, IV (20), 197. 
and women, which he considered the most important natural remedy ${ }^{24}$. He also used water treatment, following the method of Rev. Kneipp, however, greatly relaxed. "Water treatments, which are the most important therapeutic agent in most modern spas, although widely used in Kosów, are considered by Dr Tarnawski to be a secondary matter compared to the above-mentioned air bath and, however, important gymnastics from it" 25 - was reported in correspondence from igi2.

\section{TREATMENT METHODS AND TREATMENTS USED}

He paid a lot of attention to his diet, recommending moderation and temperance. When he warned about excessive meals, he used to say: "Don't overfeed and you won't get sick" 26 . In addition to diet, he also used other means, i.e. sleeping outdoors, barefoot running, bathing in an icy mountain river, gymnastic and breathing exercises, and physical work (so-called intelligence work, garden work), and dancing.

These classes were performed from early morning to evening, by children, adolescents, and adults. Water treatment took place in bathrooms with a glass roof, in which there was a lot of sun and fresh air, as well as walking barefoot on dew and wading, and a river bath in Rybnica ${ }^{27}$. He was a proponent of returning to nature, so he paid a lot of attention to barefoot walking and foot hygiene. He believed that hardening of the feet affects the whole body, that radioactivity of the earth passes more easily through the bare feet and thus strengthens the nervous system. According to him, it was best to

24 A. Tarnawski used for treatment both natural sun rays and those produced using the helioreflector he constructed - a solar (solar) bath awarded with a medal at the natural and medical exhibition in Lwów in 1907. The therapy consisted in subjecting the patient to sunlight in the lampshade glass, whose side and back walls were equipped with a number of mirrors, increasing the strength of rays. Tarkowska, Natalia (2016), Healing House of the Nation. Culture-forming role of the Apolinary Tarnawski Institute of Natural Medicine in Kosów in Pokuta (1893-1939), Kraków, 63-154.

25 Hygienic way! (1912), Ruch, VII (17-18), 179.

26 Tarnawska-Busza, C. (1980), 80. Depending on the therapeutic indications, a mixed diet was used: meat or vegetarian (without meat). Every meal was full of vegetables and fruits. Alcohol, coffee and tea containing drinks were excluded. The specialist chef prepared vegetarian meals according to recipes from a book prepared by the wife of R. Tarnawska. Fasting, or dieting, was also widely used. Tarnawski believed that it was "the most effective remedy in natural medicine" in chronic diseases, and said about its effectiveness that it "heals, strengthens, rejuvenates". Kowalenko, H. (1973), 17; Tarnawski A. (1925), 4-5; Tarnawski, W. (1960), 115; Tarnawska, Romualda (1901), Vegetarian cuisine used in the Clinic of Apolinary Tarnawski in Kosów, Lwów; Tarnawska, Romualda, Tarnawski, Apolinary (1929), Kosów vegetarian cuisine, Warszawa.

27 Kowalenko H. (1973), 16-17. 
walk on moist soil or dew, which contained hydrogen peroxide, acting as congestion and disinfectant. Added to this were the beneficial effects of air and sun. He was not used to this type of treatment and recommended tips on how to harden feet ${ }^{28}$. "At a time when the whole world, under the influence of misunderstood bacteriology, avoided infections and colds, Kosów had the courage to promote air bathing, work, and sleep with windows open"29 - was written about the method of Dr Tarnawski.

In addition to sun-air baths and water, patients were also given both a massage (performed by the bathroom service and doctors) and self-massage. The physical activity, which he ordained to children, adolescents, and the elderly, from early morning to evening, took various forms and varied, depending on the physical condition. "Life is a movement. Man breathes, working with lung muscles like a bellows, and generally strong muscles affect the efficiency and bravery of all organs, so exercising them through work and movement (gymnastics) not only maintains health and life, but also affects heart development and blood circulation" 30 - he wrote in I913. Among many forms of movement, he recommended morning gymnastics, with and without equipment, sports games, hiking, and gardening, which was supposed to be a combination of movement in the open air and a vegetarian diet, to strengthen and harden the body in the sun and air. Breathing exercises were used several times a week and were combined with music, sometimes also with dancing in an outdoor gym. A combination of the rhythm of movement with music was also used, especially in health resorts, where weak patients with an impaired balance of the sensory and motor system were often found.

These classes were to develop a sense of rhythm and improve joint mobility. This is confirmed by the statement from r9I3: "An example of this is found in the famous plant of natural medicine in Kosów, where - next to gymnastics in the Ling system, extra-physical training and bodily workout and sports - patients practice several times a week to the music" ${ }^{31}$. In addition, trips were organised every day, which gave the possibility of outdoor movement, combined with deep breathing. In the therapy conducted at the

28 Tarnawski, Apolinary (1925b), On barefoot walking and leg care, Wychowanie Fizyczne, VI (1), 87-93; id. (1925c), Barefoot walking and leg care, Higjena Ciała i Sport, I (2), 27-29.

29 Tuchendler, A. (1931), 148.

30 Tarnawski, A. (1913), 158.

31 Kozłowski, Władysław (1913), Uneducated exercise, Ruch, VIII (23), 294. 


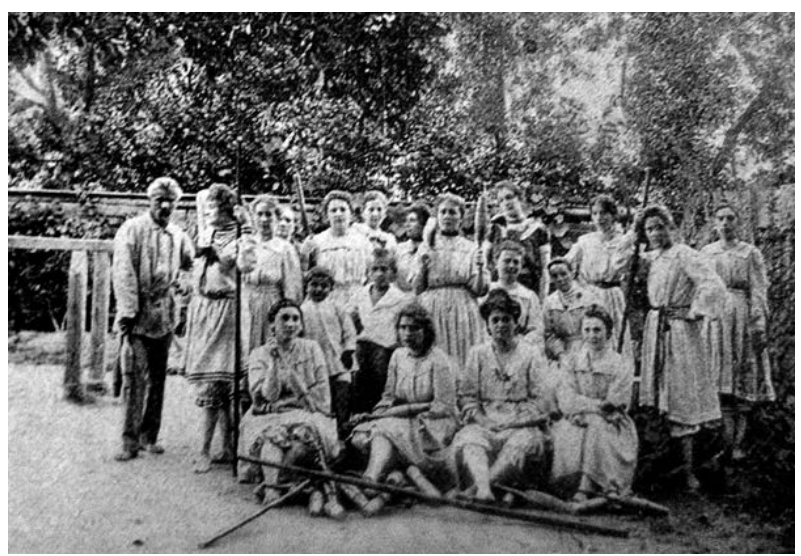

Figure I. Dr Tarnawski (first from the left) with a group of women in his clinic in Kosów. (Source: Przegląd Zdrojowo-Kąpielowy (I9I3), Io, 3).

Department, the silence was appreciated, and it was also recommended in everyday life ${ }^{32}$.

Life in the plant was organised based on the regulations that were in force when the company gate was crossed. In the first points of it, there was an indication to follow the rules, which was associated with achieving the best results in treatment. The following points recorded the working hours of the referring physician and auxiliary physicians. The regulations also described the ordination book, in which the doctor wrote down all the instructions regarding the treatment measures. There, the attending physician assigned the patient the doctor who was to look after the patient. It was important to observe the time during the treatment because all treatments had specific hours ${ }^{33}$.

32 Tarnawski, A. (1925), 3-10; Dr Tarnawski in Kosovo (1925), Higjena Ciała i Sport, I (2), 3435; Kowalenko, H. (1973), 18; Tarnawska-Busza, C. (1987), 144-147; Hygienic way! (1912), 180; Tarnawski, Apolinary (1909), Explanation of the method of treatment in the clinic of Dr A. Tarnawski in Kosów in Galicya.

33 For example, walking on dew took place before $6.00 \mathrm{a} . \mathrm{m}$. Hydrotherapy treatments in the full season lasted up to 12 hours, and usually took place between 8.00 and 11.00 until noon and between 15.30 and 17.00 in the afternoon. The latecomers lost their endeavours. Exceptions in the hours of hydrotherapy treatments were during Sundays and holidays because of the earlier release of the plant home service. Sunbathing also had a specific schedule throughout the day, and it was from 10.00 to 12.00 and from 14.00 to 16.00 in the afternoon. Only the massage hours did not have a fixed time set. Patients ate only three meals, served at regular times - breakfast between 7.00 and 8.00 in the morning, lunch at 12.30, and dinner at 18.10. Tarnawski, A. (1925), 9-10; id. Program of the Tarnawski Institute of Natural Medicine in Kosów near Kołomyja East Youth (1933), Lwów, 19-20; Tarnawski, A. (1920), 29-38. 
All treatments were supervised by doctors who monitored the patients. In conversations and readings, doctors explained the importance of a hygienic lifestyle while giving tips on how to gain and maintain health and life energy in the future. During treatment, the importance of a proper lifestyle and the fact that patients should strictly follow the doctor's instructions were emphasized. Some even thought that the good curative results at the Kosów Clinic were the result of a lifestyle that was consistently followed there. Introducing the patient to the right lifestyle was also his daily training for the future ${ }^{34}$. The importance of patients' awareness of health improvement in spas after returning home is evidenced by the fact that in 1923 , i.e. at the time of the greatest development of the Kosów Clinic, in the "Polish Medical Gazette" and the magazine "Health", Dr Tarnawski proposed the creation of "common hygienic universities" in Polish spas, i.e. courses that were to be conducted in the form of lectures that patients should attend during their stay. He also proposed establishing the Society of Friends of Health, which would promote hygiene in the home and public life. Unfortunately, none of these ideas has been implemented ${ }^{35}$.

Apolinary Tarnawski was a supporter of natural healing methods since the beginning of his work, and he applied drugs only in severe cases because, as he said, "the medicine is a jack that allows the car to move if it gets stuck in the mud. It must go on its own" ${ }^{\text {" }}$. Among the diseases, that were expected to improve after a visit to the clinic of Dr Tarnawski, were mainly chronic diseases, i.e. impaired metabolism (obesity, diabetes, atherosclerosis) and related arthritic and rheumatic ailments (gout), and nervous system diseases (neurasthenia, migraines, neuroses, chorea). Among the indications for treatment were also Basedow's disease, gastrointestinal (stomach and intestinal) and abdominal diseases (atonia, jaundice), female diseases, respiratory diseases, skin disorders (psoriasis, eczema), cardiovascular diseases (light), varicose veins, anaemia, jaundice, proteinuria, mercury poisoning, nicotine, rickets in children. Patients with pulmonary tuberculosis, infectious diseases, fevers, bedridden and mentally ill patients and epileptics were not admitted ${ }^{37}$.

34 Chmieleński, K. (1933), On the significance of the regime in spa treatment, Nowiny Społeczno-Lekarskie, VII (10), 147; Tarnawski, A. (1911), 177-182.

35 Tarnawski, A. (1911), 182; Tarnawski, Apolinary (1923), Project to create universities for hygiene in health resorts, Life, 17/1923, 2; Pruszyńska, A. (2000), 126.

36 Tarnawska-Busza, C. (1987), 147.

37 Tarnawski, A. (1925), 9-10; Tarnawski, Apolinary (1910), On neurasthenia, its causes and prevention, Ruch, V (10), 115-117; (b) 11, 130-132; (c) 14, 161-163. 


\section{TARNAWSKI AS A HEALTH PROMOTER}

This real "genius from Kosów", sometimes harsh on patients, especially the obese, created his own system of natural treatment of "body and spirit". In the interwar period, mainly the intelligentsia and landowners, as well as the cultural and artistic elite of Warszawa came to his Clinic called the "health school". The motto of the Clinic was "Rule Yourself", and it was about abstinence from drinking, smoking, gambling, and debauchery. So everyone who came to the Clinic had to comply with the recommendations and be prepared to change their current lifestyle. "They tell them to take control of oneself when they feel such or such deficiencies, they advise to get rid of the harmful habits that have so far been a relief to their suffering; they convince those who have been weak to be tough during the treatment; they force those who cannot live without meat to become vegetarians" ${ }^{\prime 38}$-it was reported in the correspondence before the First World War.

Admired by some, criticised by others, he introduced many new health solutions and ideas in the interwar period: "Dr A. Tarnawski, who with unbending energy overcame himself the enormous effort of pioneer work and fought over mountains of prejudice and exaggeration, can today - not without pride - look at the yield of efforts undertaken with the sole thought of serving the society" ${ }^{19}$ - it was already mentioned in 1922. After a dozen or so years, it was similar, because every mention in the press of Kosów evoked thoughts about the natural medicine facility: "About Tarnawski and his Clinic in Kosów, it was used to be the only natural medicine centre in Poland. There is probably no person in Poland who did not know or hear anything about Kosów, although people usually tell each other anecdotal stories about the relentless creator of the Clinic and its < bizarre > method. Just say <Kosów. Dr Tarnawski>, and immediately will come back <fasting, walking barefoot, getting up at dawn, gymnastics, chopping wood $>$ "

Tarnawski was a great patriot, and the clinic became a specific expression of his devotion to the homeland, which was based on the idea of healing the nation. In addition, and perhaps even most important - Tarnawski and the entire Tarnawski family in Kosów, through their work and social activities,

\footnotetext{
Hygienic way! (1912), 178; Tarnawski, A. (1910c), 163.

Kordys, R. (1922), 4.

Zembrzuska-Gurzyńska, Wanda (1936), Kosów as a bastion of Polishness, Nowy Kurjer, 236/1936.
} 
guarded not only the health of Poles but also their endangered state and national interests in this eastern region ${ }^{41}$.

Before the outbreak of World War II, the development of the Natural Medicine Plant in Kosów reached its highest level. Tarnawski planned to transform his plant into a school called Janissary Health. The plant was initially to maintain the school until it became self-sufficient. It was supposed to be a natural medicine school for the upbringing of youth at the Institute, with an emphasis on the obligatory vegetarian milk diet, body exercises (ordinary and breathing gymnastics, hydrotherapy, trips, and games), garden work. Unfortunately, the outbreak of war thwarted those plans ${ }^{42}$.

The popularity enjoyed by the Kosów Clinic caused that similar establishments based on the "Kosów" treatment system also began to appear in other regions of Poland. "I don't know if he would find himself in the world outside Poland, in which certain summer resorts or health resorts would play a more important role in his culture. In Poland, however, there were places which, by means of saturation of their spiritual atmosphere, ideological current, mental and artistic input, and the lifestyle itself represented an important position in the cultural achievements of the nation [...]. As in Zakopane, Kosów met many outstanding Poles from three districts, both before and after World War I. Many a concept of Polish politics was born there in the times that preceded independence [...]. Kosów was a brick in the building of national culture - beautiful, valuable, original and very Polish" ${ }^{33}$ - wrote in 1970 in emigration memories Ignacy Wieniewski, Polish literary historian and essayist.

41 The Tarnawski family was involved in charity work in Kosów among Poles, who constituted $10 \%$ of the population in Kosów. They were patrons, organisers, or collaborators of many Polish institutions and organisations. They founded a reading room, the District Agricultural Society, housewife circles, built the People's House, organised, among other things, summer camps for poor children, they set up an educational institution for youth, assisted in running an orphanage, a Catholic association of female and male youth. Ibid.

42 The school was to be for everyone, regardless of class differences, scholarships were planned for the poorest. The school graduates were to fight for the health ideas of the whole society in the future. Education at school was to last for two years. The program was supposed to be such that young people would not lose the school year. In addition to school classes, farming, animal husbandry, civic duties, hygiene lectures, talks about nutrition, lectures on religion, learning the composition of foods and their preparation were envisaged. Tarnawska-Busza, C. (1987), 151-152; Dr Tarnawski's natural medicine plant in Kosów near Kołomyja (1937), in: Album of Polish Spas. Dedicated to the XV Congress of Polish Doctors and Naturalists in Lwów in July 1937, Bydgoszcz, 24.

43 Kałuski, Marian (2017), Poles in the Hutsul region, Dziennik Kijowski, 14 (549), 3; Wieniewski, Ignacy (1970) Kosów, [in:] Kaleidoscope of Memories, from W. Tarnawski (1970), published by Polish Cultural Foundation, London. 


\section{Summation}

According to the information presented, at the turn of the century, more and more people were convinced that the sun, air, water, and movement were important, and sometimes could replace the best drugs. The concept of direct contact with nature was not an end in itself, but only a means leading to the achievement of the greatest physical fitness on the one hand, and on the other hand, positively influenced the psyche and nervous system of modern man, locked in the narrow city walls, in the so-called rush of life ${ }^{44}$. It was argued that "Who wants to be healthy must live in harmony with air, sun, and water. The first exercise is deep breathing, which spreads invigorating oxygen through our tissues, it is a real elixir of life" ${ }^{34}$.

Doctor A. Tarnawski was undoubtedly the precursor of modern natural medicine, preventive medicine, and geriatric physiotherapy in Poland. Based on the experience gained from foreign scientific travel, his own knowledge, and experience, he developed an original method that he successfully used in his clinic in Kosów. His assumptions proved to be timeless and have not lost their relevance despite the passage of many years.

44 Mal, T. (1927), Sun, air and movement, Start, I (5), 8.

45 Majewska, Gabryela (1927), Physical revival, Start, I (10), 11. 


\section{BiBLIOGRAPHY}

1. Apolinary Tarnawski (2000), [in:] Pruszyńska, Agnieszka (2000), Medical Memorabilia in the Archives of the Polish Institute and the Museum of General W. Sikorski in London, Modern Medicine, 7, 1.

2. Chmieleński, K. (1933), On the significance of the regime in spa treatment, Nowiny Społeczno-Lekarskie, VII, 10.

3. Dr A. Tarnawski, Physical and Dyethetic Therapy Center in Kosów (after Kołomyja) (1904), [in:] Górski, Xawery ed., (1904), Polish Guide to Spas, published by Przegląd Zdrojowy, Kraków.

4. Dr Tarnawski's natural medicine plant in Kosów near Kołomyja (1937), [in:] Album of Polish Spas. Dedicated to the XV Congress of Polish Doctors and Naturalists in Lwów in July 1937, Bydgoszcz.

5. Dr Tarnawski in Kosów (1925), Higjena Ciała i Sport, I, 2.

6. Draz, Stefan (1909), Modern university of health, Ruch, IV, 20.

7. Hygienic way! (1912), Ruch, VII, 17-18.

8. Jandziś, Sławomir, Pleśniak, Andżelika, Zaborniak, Stanisław, Kiljański, Marek (2015), The original natural healing method of Dr Apolinary Tarnawski used at the Plant in Kosów in 1893-1939, Polish Journal of Physiotherapy, XV, 1.

9. Jankowiak, Józef (1962), Profiles of distinguished promoters of natural medicine methods. Biography of Dr Apolinary Tarnawski, Wiadomości Uzdrowiskowe, XVII, 1.

10. Kałuski, Marian (2017), Poles in the Hutsul region, Dziennik Kijowski, XIV, 549.

11. Kieniewicz, Stefan (1996), History of Poland 1795-1918, Warszawa.

12. Kordys, Roman (1922), Undermining the spa, Słowo Polskie, 211/1922.

13. Kowalenko, Halina (1973), Apolinary Tarnawski - a precursor of the prevention of civilization-related harm, Polish Balneology, XVIII, 1-3.

14. Kozłowski, Władysław (1913), Uneducated exercise, Ruch, VIII, 23.

15. Lewicki, Stanisław, Orłowicz, Mieczysław, Praschil, Tadeusz (1912), Guide to Galicyi spas and climatic resorts including: spas, spas, health resorts, summer resorts, climatic resorts, and towns with mineral springs, as well as tourist and winter sports facilities, Lwów.

16. Majewska, Gabryela (1927), Physical revival, Start, I, 10.

17. Mal, T. (1927), Sun, air and movement, Start, I, 5.

18. N.N., Correspondence, Przegląd Zdrojowo-Kąpielowy, (1913), XII, 10, 3.

19. Polish Balneology (1973), XVIII, 1-3.

20. Polish spas. Guide to health resorts affiliated to the Association of Polish Spas (1932), Warszawa. 
21. Polish Guide Spas (1934), Kraków.

22. Seasonal report from the Institute of Natural Medicine Dr Tarnawski in Kosów (1935), [in:] Diary of the Polish Balneological Society (1935), XIV.

23. Spas and spas in Poland. Illustrated guidebook for 1927 (1926), Warszawa.

24. Tarkowska, Natalia (2016), Healing House of the Nation. Culture-forming role of the Apolinary Tarnowski Institute of Natural Medicine in Kosów in Pokuta (1893-1939), Kraków.

25. Tarnawska, Romualda (1901), Vegetarian cuisine used in the clinic of Apolinary Tarnawski in Kosów, Lwów.

26. Tarnawska, Romualda, Tarnawski, Apolinary (1929), Kosów vegetarian cuisine, Warszawa.

27. Tarnawska-Busza, Celina (1980), Dr Apolinary Tarnawski. Pioneer of natural medicine and geriatrics in Poland, Bulletin. Circle of Lwów, XIX, 38.

28. Tarnawska-Busza, Celina (1987), Doctor Apolinary Tarnawski. Precursor of natural medicine and geriatrics in Poland, Problemy Uzdrowiskowe, 29, 9-10.

29. Tarnawski, Apolinary (1909), Explanation of the method of treatment in the clinic of Dr A. Tarnawski in Kosów in Galicia.

30. Tarnawski, Apolinary (1910), On neurasthenia, its causes and prevention, Ruch, $\mathrm{V}, 10,11,14$.

31. Tarnawski, Apolinary (1911), Hygiene on a normal day, Ruch, VI, 17-18.

32. Tarnawski, Apolinary (1913), Natural Medicine, Ruch, VIII, 12.

33. Tarnawski, Apolinary (1920), Prospectus of Dr Tarnawski's hygiene clinic in Kosów, Kraków.

34. Tarnawski, Apolinary (1923), Common universities in spas, Polska Gazeta Lekarska, II, 23.

35. Tarnawski, Apolinary (1923), Project to create universities for hygiene in health resorts, Life, 17/1923.

36. Tarnawski, Apolinary (1925), Barefoot walking and leg care, Higjena Ciała i Sport, I, 2.

37. Tarnawski, Apolinary (1925), On barefoot walking and leg care, Wychowanie Fizyczne, VI, 1.

38. Tarnawski, Apolinary (1925), Program of Dr Tarnawski’s Clinic in Kosów, Lwów.

39. Tarnawski, Apolinary (1933), Program of the Tarnawski Institute of Natural Medicine in Kosów near Kołomyja East Youth, Lwów.

40. Tarnawski, Apolinary (1980), Hygiene of old age and aging, London.

41. Tarnawski, Witt (1966), My Father, London. 
42. Tuchendler, Antoni (1931), Our native natural medicine in Kosów, Nowiny Społeczno-Lekarskie, V, 9.

43. Wieniewski, Ignacy (1970), Kosów, [in:] Kaleidoscope of Memories, from W. Tarnawski (1970), published by Polish Cultural Foundation, London.

44. Zembrzuska-Gurzyńska, Wanda (1936), Kosów as a bastion of Polishness, Nowy Kurjer, 236/1936.

\section{SAŽETAK}

Liječnik Apolinary Tarnawski (1851. - 1943.) nedvojbeno je bio preteča moderne prirodne medicine, preventivne medicine i gerijatrijske fizioterapije u Poljskoj. Na temelju iskustva stečenog na inozemnim znanstvenim putovanjima te vlastita znanja $i$ iskustva razvio je originalnu metodu kojom se uspješno koristio u vlastitoj klinici u Kosówu. Njegove su se pretpostavke pokazale bezvremenima i unatoč protoku mnogih godina nisu izgubile na značenju.

Ključne riječi: povijest medicine, fizioterapija, terapeutska gimnastika, fizikalna medicina 